\title{
DAT1, DRD4, and DRD5 Polymorphisms Are Not Associated With ADHD in Dutch Families
}

\author{
Steven C. Bakker, ${ }^{1 *}$ Emma M. van der Meulen, ${ }^{1}$ Nicole Oteman, ${ }^{2}$ Hedi Schelleman, ${ }^{4}$ Peter L. Pearson, ${ }^{2}$ \\ Jan K. Buitelaar, ${ }^{3}$ and Richard J. Sinke ${ }^{2}$ \\ ${ }^{1}$ Department of Psychiatry, University Medical Center Utrecht, The Netherlands \\ ${ }^{2}$ Department of Medical Genetics, University Medical Center Utrecht, The Netherlands \\ ${ }^{3}$ Department of Psychiatry, University Medical Center Nijmegen, The Netherlands \\ ${ }^{4}$ Department of Biostatistics and Epidemiology, Erasmus MC, Rotterdam, The Netherlands
}

\begin{abstract}
Recent meta-analyses have indicated that the dopamine transporter gene (DAT1) and the dopamine receptor genes D4 (DRD4) and D5 (DRD5) are associated with attention-deficit hyperactivity disorder (ADHD), although single studies frequently failed to show significant association. In a family-based sample of 236 Dutch children with ADHD, we have investigated the previously described variable number of tandem repeat (VNTR) polymorphisms and two additional microsatellites at the DAT1 and DRD4 loci. DRD5 was investigated using the microsatellite that was previously found to be associated. Transmission disequilibrium tests (TDTs) did not show preferential transmission of alleles or two-marker haplotypes to affected offspring. These data suggest that DAT1, DRD4, and DRD5 do not contribute substantially to ADHD in the Dutch population. () 2004 Wiley-Liss, Inc.
\end{abstract}

KEY WORDS: ADHD; association study; DAT1; DRD4; DRD5

\section{INTRODUCTION}

Attention-deficit hyperactivity disorder (ADHD) is the most common child psychiatric disorder, affecting 4-5\% of children in western countries [Buitelaar, 2002]. The estimated contribution of genetic factors is approximately $80 \%$ [Levy, 1997; Thapar et al., 1999], and it is likely that multiple genetic and environmental factors interact in causing the disease. Genetic research has focused on genes involved in neurotransmission, and in particular the dopaminergic system, since effective medication was reported to block the reuptake of dopamine by the dopamine transporter molecule (DAT1) [Krause et al., 2000]. Three dopaminergic genes have recently been reported to be associated with ADHD in meta-analyzes of data from multiple studies. The DAT1 gene has a variable number of tandem repeat (VNTR) polymorphism in the $5^{\prime}$ untranslated region (UTR). A recent meta-analysis concluded that having a 10-repeat allele increased the risk to develop ADHD by a factor

*Correspondence to: Steven C. Bakker, Department of Psychiatry, A 00.241, University Medical Center Utrecht, PO Box 85500, 3508 GA Utrecht, The Netherlands.

E-mail: s.c.bakker@med.uu.nl

Received 20 March 2004; Accepted 11 May 2004

DOI 10.1002/ajmg.b.30089 of approximately 1.3 [Maher et al., 2002]. The VNTR may change DAT1 function, since it has been suggested to regulate gene expression [Michelhaugh et al., 2001; Mill et al., 2002].

The dopamine receptor D4 gene (DRD4) has a VNTR polymorphism in the third exon, which is part of the third intracellular loop of the receptor, and may therefore have functional relevance [Asghari et al., 1995; Schoots and Van Tol, 2003]. Recent meta-analyses confirmed that the 7-repeat allele increased the risk of developing ADHD 1.4-2.0 times [Faraone et al., 2001; Maher et al., 2002]. Children with the 7-repeat allele were found to have a more inaccurate, impulsive response style on neuropsychological tasks [Langley et al., 2004].

In a meta-analysis of data from 14 different centers, the common 148 base pair (bp) allele of a compound microsatellite located 18.5 kilobases $(\mathrm{kb})$ from the dopamine receptor D5 gene (DRD5) was shown to be significantly associated with ADHD (odds ratio 1.24) [Lowe et al., 2004].

The three polymorphisms mentioned above, as well two additional microsatellites near the VNTRs in DAT1 and DRD4, were genotyped in a sample of 236 Dutch children from 144 families.

\section{SUBJECTS AND METHODS}

Most children $(n=198)$ were part of a previously described sample of sib pair families [Bakker et al., 2003]. Children were only included if they had ADHD of the inattentive, hyperactive, or combined subtype, according to DSM-IV criteria. Children with autism spectrum disorders were excluded. This sample was extended with 38 families with only 1 affected child, diagnosed using the same criteria. In five families, no DNA from the father was available.

DNA was isolated as described [Bakker et al., 2003]. The VNTR polymorphisms in the DAT1 and DRD4 genes were amplified using previously described PCR primers [Van Tol et al., 1992; Cook et al., 1995]. Reactions were performed in $50 \mu \mathrm{l}$, containing $50 \mathrm{ng}$ of genomic DNA, $100 \mathrm{ng}$ of forward primer and $100 \mathrm{ng}$ of reverse primer, $150 \mathrm{mM}$ of each dNTP, $67 \mathrm{mM}$ Tris $\mathrm{HCl}, 6.7 \mathrm{mM} \mathrm{MgCl}, 10 \mathrm{mM} \beta$-mercaptoethanol, $6.7 \mu \mathrm{M}$ EDTA, $16.6 \mathrm{mM}\left(\mathrm{NH}_{4}\right)_{2} \mathrm{SO}_{4}, 10 \%$ DMSO, $7.5 \mu \mathrm{g}$ BSA, and $0.4 \mathrm{U}$ of AmpliTaq polymerase (Applied Biosystems, Foster City, CA). PCR reactions were performed on a ABI 9600 GeneAmp PCR system (Applied Biosystems) using the following conditions: 2 min at $94^{\circ} \mathrm{C}$, followed by 33 cycles of $30 \mathrm{sec}$ at $94^{\circ} \mathrm{C}, 30 \mathrm{sec}$ at $60^{\circ} \mathrm{C}$ (DAT1) or $54^{\circ} \mathrm{C}$ (DRD4), 2 min at $72^{\circ} \mathrm{C}$ and a final extension of $4 \mathrm{~min}$ at $72^{\circ} \mathrm{C}$. Subsequently, $10 \mu \mathrm{l}$ of PCR product was analyzed on a $3 \%$ agarose gel, by applying $125 \mathrm{~V}$ for a duration of $2 \mathrm{hr}$. Fragments were stained with ethidium bromide and sizes were determined using a PGEM DNA size marker (Promega, Leiden, The Netherlands). In order to determine the repeat numbers of the different alleles of both genes, sequence analysis of the repeat regions were performed in several individuals. The DRD4 mononucleotide repeat, 
located in intron 1, was amplified with primers ACAGGCCCTGAGGTTTCC and GTGGGGAAGGGGTGTTTC [Petronis et al., 1994]. Primers for dinucleotide repeat D5S2005, which is located at $50 \mathrm{~kb}$ from the DAT1 VNTR, were obtained from the Ensembl database [www.ensemble.org]. These microsatellites, as well as the DRD5 repeat [Daly et al., 1999], were amplified and analyzed as described elsewhere [Bakker et al., 2003]. Two independent raters scored all genotype data, and when they disagreed genotyping was repeated. Inheritance consistency was verified using the Pedcheck program [O'Connell and Weeks, 1998], and in case of inconsistencies the entire family was "zeroed out" for one marker. HardyWeinberg equilibrium (HWE) was investigated using the GENEPOP program for multi-allelic markers [Raymond and Rousset, 1995]. Likelihood ratios for transmissions of marker alleles and haplotypes from parents to affected offspring, as well as linkage disequilibrium (LD) between markers, were calculated using the TDTPHASE program [Dudbridge, 2003]. This estimates missing haplotypes using the expectation maximization (EM) algorithm, and uses unconditional logistic regression on the full likelihood of parents and offspring. Only alleles and haplotypes with frequencies higher than 0.05 were taken into account. $P$ values were not corrected for multiple testing.

\section{RESULTS}

All five markers were in HWE in parents as well as in children. Results of overall likelihood tests for single markers and marker haplotypes are shown in Table I. There were no signs of a distorted transmissions of any of the single polymorphisms, or of single alleles. As genetic markers, both VNTRs are not very informative, with heterozygosity values below 0.5 , and this could be one explanation for the replication problems in previous studies. In order to increase the information content, we also analyzed two-marker haplotypes with polymorphic microsatellites for DAT1 and DRD4. LD between the DRD4 markers was substantial for the DRD4 polymorphisms ( $\mathrm{D}^{\prime}=0.59$ ), but lower for the DAT1 polymorphisms $\left(D^{\prime}=0.20\right)$, which is in agreement with a previous study [Hawi et al., 2003]. Overall, no haplotypes were significantly associated.

\section{DISCUSSION}

In this Dutch family-based sample, which is one of the largest described so far, no association was found between the DAT1, DRD4, or DRD5 genes and ADHD. The DRD5 data presented in detail here were part of the recent multi-center analysis for this gene, in which the Dutch sample was one of the two studies that did not contribute to the overall detected association [Lowe et al., 2004]. These findings seem to be in agreement with the results of our recent whole genome scan, in which there were no indications for linkage in the chromosomal regions that contain the three genes [Bakker et al., 2003]. The power of the linkage study, however, may have been too low to detect small effects. Likewise, we cannot rule out that our negative findings, as well as those by others, are due to chance, given the low relative risks attributed to the individual genes, or due to insufficient LD with an unknown disease-related variant. It is also possible, however, that these genes do not play an equally important role in all populations, or in multiplex families as compared to sporadic cases [Daly et al., 1999]. In another recent study in a large sample of multiply affected families, the DAT1 and DRD4 VNTRs also did not show a distorted transmission, although a different DRD4 polymorphism, as well as the DRD5 microsatellite, were positively associated with ADHD [Kustanovich et al., 2003]. Now that combined studies have quite convincingly suggested a small
TABLE I. Results of Transmission Disequilibrium Tests (TDTs) for Single Markers and 2-Marker Haplotypes

\begin{tabular}{|c|c|c|c|c|c|}
\hline Marker/haplotype & Allele & $\mathrm{T}$ & Freq-T & NT & Freq-NT \\
\hline DRD4 VNTR & 2 & 42 & 0.10 & 52 & 0.13 \\
\hline \multirow[t]{3}{*}{$P=0.50$} & 4 & 277 & 0.68 & 265 & 0.65 \\
\hline & $7^{*}$ & 71 & 0.17 & 67 & 0.16 \\
\hline & Other & 19 & 0.05 & 25 & 0.06 \\
\hline DRD4 mono & 2 & 103 & 0.23 & 105 & 0.24 \\
\hline \multirow[t]{3}{*}{$P=0.71$} & 4 & 274 & 0.62 & 282 & 0.64 \\
\hline & 5 & 63 & 0.14 & 55 & 0.12 \\
\hline & Other & 2 & 0.00 & 0 & 0.00 \\
\hline Haplotype DRD4 & 2_2 & 15 & 0.04 & 24 & 0.06 \\
\hline \multirow[t]{5}{*}{$P=0.65$} & 2_4 & 26 & 0.07 & 25 & 0.06 \\
\hline & 4_4 & 206 & 0.52 & 204 & 0.51 \\
\hline & 4_5 & 49 & 0.12 & 44 & 0.11 \\
\hline & $7 \_2$ & 54 & 0.14 & 58 & 0.15 \\
\hline & Otherer & 46 & 0.12 & 41 & 0.10 \\
\hline DAT1 VNTR & 9 & 96 & 0.22 & 92 & 0.21 \\
\hline \multirow{2}{*}{$P=0.73$} & $10^{*}$ & 341 & 0.77 & 346 & 0.78 \\
\hline & Other & 5 & 0.01 & 4 & 0.01 \\
\hline D5S2005 & 4 & 221 & 0.52 & 214 & 0.50 \\
\hline \multirow[t]{4}{*}{$P=0.54$} & 5 & 99 & 0.23 & 96 & 0.23 \\
\hline & 6 & 60 & 0.14 & 55 & 0.13 \\
\hline & 7 & 23 & 0.05 & 33 & 0.08 \\
\hline & Other & 21 & 0.05 & 26 & 0.06 \\
\hline Haplotype DAT1 & $9 \_4$ & 33 & 0.08 & 32 & 0.08 \\
\hline \multirow{5}{*}{$P=0.21$} & $10 \_4$ & 178 & 0.44 & 172 & 0.42 \\
\hline & $10 \_5$ & 75 & 0.18 & 79 & 0.19 \\
\hline & $10 \_6$ & 45 & 0.11 & 38 & 0.09 \\
\hline & $10 \_7$ & 11 & 0.03 & 25 & 0.06 \\
\hline & Other & 66 & 0.16 & 62 & 0.15 \\
\hline DRD5 & 4 & 27 & 0.07 & 26 & 0.06 \\
\hline \multirow[t]{7}{*}{$P=0.32$} & 5 & 19 & 0.05 & 25 & 0.06 \\
\hline & 8 & 34 & 0.08 & 25 & 0.06 \\
\hline & $9 *$ & 183 & 0.45 & 186 & 0.46 \\
\hline & 10 & 48 & 0.12 & 41 & 0.10 \\
\hline & 11 & 29 & 0.07 & 38 & 0.09 \\
\hline & 12 & 11 & 0.03 & 21 & 0.05 \\
\hline & Other & 55 & 0.14 & 44 & 0.11 \\
\hline
\end{tabular}

Overall $P$ values of likelihood tests are shown in italic print below the marker names. Allele numbers of the variable number of tandem repeats (VNTRs) indicate repeat numbers; previously reported at-risk alleles are indicated with an asterisk (*). T/NT, number of transmitted/non-transmitted alleles. Freq-T/Freq-NT, frequency of transmitted/non-transmitted alleles. Twomarker haplotypes are indicated by the alleles of the respective markers, separated by an underscore ( ). Other, combined numbers/frequencies of all alleles and haplotypes with frequencies $<0.05$.

but significant role for dopaminergic genes in ADHD, further studies in different samples seem to be required to assess their role as general risk factors across populations.

\section{REFERENCES}

Asghari V, Sanyal S, Buchwaldt S, Paterson A, Jovanovic V, Van Tol HH 1995. Modulation of intracellular cyclic AMP levels by different human dopamine D4 receptor variants. J Neurochem 65(3):1157-1165.

Bakker SC, van der Meulen EM, Buitelaar JK, Sandkuijl LA, Pauls DL Monsuur AJ, van't Slot R, Minderaa RB, Gunning WB, Pearson PL, et al 2003. A whole-genome scan in 164 Dutch sib pairs with attention-deficit/ hyperactivity disorder: Suggestive evidence for linkage on chromosomes $7 \mathrm{p}$ and 15q. Am J Hum Genet 72(5):1251-1260

Buitelaar JK. 2002. Epidemiology: What have we learned over the last decade? In: Sandberg S, editor. Hyperactivity and attention-deficit disorders, 2nd edn. Cambridge: Cambridge University Press. pp 30-63.

Cook EH Jr, Stein MA, Krasowski MD, Cox NJ, Olkon DM, Kieffer JE, Leventhal BL. 1995. Association of attention-deficit disorder and the dopamine transporter gene. Am J Hum Genet 56(4):993-998.

Daly G, Hawi Z, Fitzgerald M, Gill M. 1999. Mapping susceptibility loci in attention deficit hyperactivity disorder: Preferential transmission of 
parental alleles at DAT1, DBH, and DRD5 to affected children. Mol Psychiatry 4(2):192-196.

Dudbridge F. 2003. Pedigree disequilibrium tests for multilocus haplotypes. Genet Epidemiol 25(2):115-121.

Faraone SV, Doyle AE, Mick E, Biederman J. 2001. Meta-analysis of the association between the 7-repeat allele of the dopamine $\mathrm{D}(4)$ receptor gene and attention deficit hyperactivity disorder. Am J Psychiatry 158(7):1052-1057.

Hawi Z, Lowe N, Kirley A, Gruenhage F, Nothen M, Greenwood T, Kelsoe J, Fitzgerald M, Gill M. 2003. Linkage disequilibrium mapping at DAT1, DRD5, and DBH narrows the search for ADHD susceptibility alleles at these loci. Mol Psychiatry 8(3):299-308.

Krause KH, Dresel SH, Krause J, Kung HF, Tatsch K. 2000. Increased striatal dopamine transporter in adult patients with attention deficit hyperactivity disorder: Effects of methylphenidate as measured by single photon emission computed tomography. Neurosci Lett 285(2): 107-110.

Kustanovich V, Ishii J, Crawford L, Yang M, McGough JJ, McCracken JT, Smalley SL, Nelson SF. 2004. Transmission disequilibrium testing of dopamine-related candidate gene polymorphisms in ADHD: Confirmation of association of ADHD with DRD4 and DRD5. Mol Psychiatry 9(7):711-717.

Langley K, Marshall L, Van Den Bree M, Thomas H, Owen M, O'Donovan M, Thapar A. 2004. Association of the dopamine d(4) receptor gene 7-repeat allele with neuropsychological test performance of children with ADHD. Am J Psychiatry 161(1):133-138.

Levy F. 1997. Attention-deficit hyperactivity disorder: A category or a continuum? Genetic analysis of a large-scale twin study. J Am Acad Child Adol Psychiatr 36(6):737-744.

Lowe N, Kirley A, Hawi Z, Sham P, Wickham H, Kratochvil CJ, Smith SD, Lee SY, Levy F, Kent L, et al. 2004. Joint analysis of the DRD5 marker concludes association with attention-deficit/hyperactivity disorder confined to the predominantly inattentive and combined subtypes. Am J Hum Genet 74(2):348-356.

Maher BS, Marazita ML, Ferrell RE, Vanyukov MM. 2002. Dopamine system genes and attention deficit hyperactivity disorder: A metaanalysis. Psychiatr Genet 12(4):207-215.

Michelhaugh SK, Fiskerstrand C, Lovejoy E, Bannon MJ, Quinn JP. 2001. The dopamine transporter gene (SLC6A3) variable number of tandem repeats domain enhances transcription in dopamine neurons. J Neurochem 79(5):1033-1038.

Mill J, Asherson P, Browes C, D’Souza U, Craig I. 2002. Expression of the dopamine transporter gene is regulated by the $3^{\prime}$ UTR VNTR: Evidence from brain and lymphocytes using quantitative RT-PCR. Am J Med Genet 114(8):975-979.

O'Connell JR, Weeks DE. 1998. PedCheck: A program for identification of genotype incompatibilities in linkage analysis. Am J Hum Genet 63(1): $259-266$.

Petronis A, O'Hara K, Barr CL, Kennedy JL, Van Tol HH. 1994. (G)nmononucleotide polymorphism in the human D4 dopamine receptor (DRD4) gene. Hum Genet 93(6):719.

Raymond M, Rousset F. 1995. GENEPOP (version 1.2): Population genetics software for exact tests and ecumenicism. J Hered 86:248-249.

Schoots O, Van Tol HH. 2003. The human dopamine D4 receptor repeat sequences modulate expression. Pharmacogenomics J 3(6):343-348.

Thapar A, Holmes J, Poulton K, Harrington R. 1999. Genetic basis of attention deficit and hyperactivity. Br J Psychiatry 174:105-111.

Van Tol HH, Wu CM, Guan HC, Ohara K, Bunzow JR, Civelli O, Kennedy J, Seeman P, Niznik HB, Jovanovic V. 1992. Multiple dopamine D4 receptor variants in the human population [see comments]. Nature 358(6382):149-152. 